\section{Dr H. Boyko}

Hugo BoYko, widely known as an ecologist of arid regions and as the founder and president of the World Academy of Art and Science, died in Israel on May 26, 1970. He was 78.

Boyko's early academic associations were with the University of Vienna, but before the Second World War he emigrated to Palestine. His early publications gave a comprehensive picture of what was then called "plant sociology". After emigration his preoccupation with the ecology of arid zones in the Mediterranean area first led him to investigate the role of plants as quantitative climate indicators and the geo-ecological law of distribution. He was particularly interested in the relations of plant ecology with hydrology and hydro-engineering, and indeed his later work concentrated chiefly on the use of salt water for the reclamation of arid zones. In 1950 he was appointed by UNESCO as a member of the international advisory mission for arid zone research, and he continued to investigate the possibilities of sea-water irrigation for the rest of his life. One practical consequence was the transformation of the desert area of Elath into a garden and resort. Boyko's ideas were set out in two books, Salinity and Aridity (1966) and Saline Irrigation for Agriculture and Forestry (1968).

In the course of his travels for this purpose, he was able to assemble a large herbarium, which covered specifically the plants of the Middle East.

Boyko's humanitarian leanings were also made explicit in his desire for international cultural cooperation. In 1956 he gave a lecture on the need for an international academy of arts and sciences at the International Conference on Science and Human Welfare in Washington. By 1960 his efforts had culminated in the founding of the World Academy of Art and Science, which has now grown to include more than three hundred fellows chosen on the strength of their intellectual achievements and their concern for human welfare. As president of the academy, Boyko was taking part in this year's conference on the environment and on society in transition, in New York, just a few weeks before he died.

\section{Professor S. J. Folley}

SyDNey JoHN Foltey, FRS, died in hospital on June 29. He was 64 years old. He had been head of the physiology department of the National Institute for Research in Dairying (University of Reading) since 1945 and a research professor of the university since 1964.

He was born in Swindon, Wiltshire, and received his early education in that county. With a county university scholarship he entered the University of Manchester in 1924, graduating in 1927 with first class honours in chemistry and with the award of the Mercer Scholarship.

After a year's postgraduate research in colloid chemistry he transferred to the physiology department and became personal assistant to Professor $H$. S. Raper. His first official university post was that of assistant lecturer in the biochemistry department at Liverpool. In 1932 he went to the NIRD as research assistant to the recently appointed physiologist, who resigned in 1933 , leaving Folley and a young technician as the entire staff of the embryo physiology department.

Folley's interest in the endocrinology of mammary function in relation to dairying was soon aroused, and with improving laboratory and animal facilities and increasing scientific assistance his original and active mind began to probe deeply into this field. He was given charge of a section of lactational physiology in 1939 . This evolved, after the war, into a full physiology department with a staff of twelve and most of the facilities necessary for experimental work on animals of all sizes.

There followed in his department an exciting period of research in which the effects of thyroxine and of pituitary hormones on milk quantity and quality, and also those of stilboestrol on mammary growth and milk production in virgin heifers, were quantitatively studied and the new knowledge firmly established. It was also demonstrated ("the first major experiment by the use of "C in Britain") that the short-chain fatty acids of milk fat were, in the ruminant, built up in the alveolar cells of the udder largely from the acetate taken up from the rumen into the circulating blood. Valuable findings were also made on the minute structure of the milk-secreting tissues and on the neuro-endocrine control of milk ejection based on a delicate method devised in his laboratory for the assay of the milk-ejection hormone, oxytocin.

These and many other physiological and biochemical problems were successfully attacked by Folley, assisted by his colleagues and visiting scientists, bringing distinction to his department, his institute and himself. He was elected a Fellow of the Royal Society in 1951 and his work has received further wide recognition both at home and abroad. In 1964 he was made an honorary doctor of veterinary medicine at the University of Ghent and he received the Dale Medal in 1969.

In his later years his failing eyesight, which deteriorated rather rapidly so that he was unable to read or work with his own hands in the laboratory, made him increasingly dependent on colleagues. But by means of tape records and other aids he was able to keep well abreast of advances in his field of research, and the successful pursuit of his work to the end was an exemplary manifestation of his courage and the devoted support of his wife.

\title{
Announcements
}

\section{University News}

Professor Robert E. Davies, professor of biochemistry at the University of Pennsylvania School of Veterinary Medicine, has been appointed Benjamin Franklin professor of molecular biology.

Dame Mary Cartwright, reader in the theory of functions in the University of Cambridge, will visit the Institute of Mathematics of the Polish Academy of Sciences and other Polish universities as Royal Society Leverhulme visiting professor.
Dr J. C. Amson, University of St Andrews, has been awarded a research grant by the Centre for Environmental Studies, London, to study the application of advanced mathematical theories to the structure, growth and stability of urban systems.

Dr D. Lack, director of the Edward Gray Institute of Field Ornithology, University of Oxford, has been appointed Royal Society visiting professor to the University of the West Indies, Jamaica, for the academic year $1970-71$. 